\title{
Prospects of payment for ecosystem services: case from water service scheme in Nepal
}

\author{
Kunju Dhakal ${ }^{1}$, Sushma Bhattarai ${ }^{2^{*}}$ and Benju Dhakal ${ }^{3}$ \\ 1,2 Tribhuvan University, Institute Of Forestry, Pokhara \\ 3 Tribhuvan University, Institute of Agriculture and Animal Science
}

\section{KEYWORDS}

\section{Ecosystem services}

Payment

Watershed

Drinking water supply scheme Problems

\begin{abstract}
Payment for ecosystem services (PES), a voluntary transaction for the optimum use of scarce natural resources, are highly recommended for conservation of forests and watershed. Despite multiple recommendations, there has not been enough studies regarding PES in Nepal, except for limited areas like hydropower plants and community forests. Every PES scheme is unique, depending upon the conditions prevalent in its site therefore more studies are required to understand appropriateness of PES mechanism. Taking drinking water scheme in Sundarijal watershed as a case, this study assessed drinking water supply scheme prevalent in the site, and prioritized its problems, and expectations, from stakeholders' perspectives. A phenomenological cross-sectional research approach was used and data were collected through in-depth interviews with major stakeholders. The result transcripts were analyzed in Atlasti version 7 and prioritized based on their frequency. The proper buying and selling mechanisms were not found in the current drinking water supply scheme in Sundarijal. The poor economic condition of users, inadequate funds in water users committee, and inadequate water collection for sales were determined as primary obstacles associated with PES establishment at the study site. Since the area has immense potential for PES, building additional water collection tanks with filter plants, a collaboration of multiple local organizations in the preparation of baseline document, identification of additional water sources, and adequate funding are perquisite to establish proper payment mechanism.
\end{abstract}

\section{Introduction}

Well-functioning ecosystems are the sources of all services essential for human survival such as forests, clean and reliable source of water, favorable weather, productive soil etc. These services are used for fulfilling basic needs, obtaining raw materials as inputs in different

* Corresponding author

E-mail address: s.bhattarai@iofpc.edu.np

Received 5 July 2021 Accepted 30 November 2021 
production plants, and base materials for development activities (Montoya and Raffaelli 2010). The services that are provided by different factors of ecosystem are vital for survival of human beings, which is a chief reason why they must be utilized in a rational manner. Loss of biodiversity, decline in soil productivity, degradation of natural state of function of such services and climate change are some of the impacts of exhaustive use of ecosystem services (Pereira et al. 2012). Economic development is dependent on resource use, but exhaustive use can cause degradation that leads to raised poverty and insecurity in a longer term (Pedersen Zari 2015).

Payment for Ecosystem Services (PES) is a highly recommended mechanism to conserve ecosystem while using it with satisfactory economic benefits (Greiber 2009; Sutton et al. 2016). PES is the voluntary transaction between consumers of any ecosystem service and the providers, who are responsible to manage the availability and access of benefits of such resources to the consumers on the basis of agreed rules of payment for generating offsite services (Wunder et al. 2018). According to Engel et al. (2008), a PES mechanism must consist of five elements namely: voluntary transaction, at least one buyer, well defined environmental services, at least one service provider, and conditionality. Formal PES for this study referred to the PES schemes which fulfilled these five criteria. PES generates multiple benefits like climate change adaptation, counteracts global loss of biodiversity, changing environment condition, and ecosystem function through a balance with economy to meet common goal of sustainable development (GC et al. 2018). Globally, countries like Indonesia, Costa Rica, Ecuador, Brazil, Bolivia, and Vietnam have successfully implemented PES schemes in their country (Wunder 2005). For example, Payments for Environmental Services Program (PESP) is the Costa Rican PES program designed for protection and enhancement of forests through specified individual contracts with small and medium sized farmers, who directly consumed forest outputs (Malavasi and Kellenberg 2002). Ecuador created employment out of the PES payment scheme whose income was spent on food, medicine and schooling of students (Wunder 2005).

PES has a significant impact on both incomes from participation and non-cash form contributing towards livelihood improvement as well as conserving the environment (Samii et al. 2014). Financial constraints remained as a major constraint of sustainable ecosystem services and lack of rules and regulation have made it difficult to effectively manage PES programs (Fauzi and Anna 2013). PES is unique in every case and in a majority of the cases, they have not fully met all the five criteria as defined by Wunder (2005). However, the modification of terms and conditions as per need in situ has allowed the scheme to be successful in the sustainable use of natural resources (Fauzi and Anna 2013; Wunder 2005). Establishment of a proper payment system, compliance and contractual obligations, equitable sharing of benefits, willingness and awareness of people about minimizing leakage, and preparation of sustainable schemes within appropriate institutional structures are some global issues that require consideration in overall PES development (Huang and Poudyal 2013).

Despite multiple recommendations, there has not been enough studies regarding PES in Nepal, except for limited areas like hydropower plants and community forest (Khatri 2010; Rosenbach et al. 2013). The study of cultural and recreational environmental services provided by Begnas lake has shown increased employment, alternate income and agriculture among the service providers and users (Poudyal et al. 2021).

It is the dire need that policy should focus on the development of PES, so that all the stakeholders could be benefited from the conservation and management of natural resources in the country 
(Kunwar 2008). Since PES is unique for any site (Wunder 2005), a proper understanding of prevailing problems, opportunities and expectations of stakeholders of PES scheme can be helpful in developing a formal PES mechanism. Taking a case of drinking water supply scheme in Nepal, this study examined the existing payment scheme to check whether the drinking water supply scheme can be referred as PES and identify prospects and challenges of developing PES in the study site which can be helpful for policy makers as well as implementers to manage sustainable waterbased PES scheme.

\section{PES-like initiatives in the past in Nepal}

PES-like initiatives were initiated from 1970 onwards in Nepal, mainly focused on tourism and watershed (Huang and Poudyal 2013). Kulekhani hydropower is one of the first PES like scheme in Nepal that created a momentum of PES intervention in Nepal (Khatri 2011). So far, there have been more than ten projects including potential scheme in ShivapuriNagarjun National Park that work as PES type initiatives in Nepal, Kulekhani Hydropower, Mohana Kailali forest corridor conservation, REDD pilot project, Conserving Rupa lake for water as ecosystem service, Shardukhola subwatershed, Dhulikhel water supply scheme, National Buffer zone management surrounding protected areas, Central Terai PES, case and Haldekhal irrigation scheme (Bhatta et al. 2014).

These PES-based programs had their benefits in terms of increased water flow to reservoirs, cash and kind payments in terms of health, education and employment to the payment receivers, good maintenance of community forest, and so on (Huang and Poudyal 2013; Smith et al. 2013). A meta analysis study done by Dhakal et al. (2020) suggested multidimensional benefits of PES schemes in the lives of marginalized people and farming women, especially regarding increased access and control over resources use and overcoming gender related barriers. Study conducted on wetlands ecosystem service at GhodaGhodi lake (Aryal et al. 2021) also suggested multiple benefits of food, and economic conditions for local people. Community forest based PES schemes had a good legislative basis and were functioning well, but required institutionalization of monitoring mechanism to ensure compliance between buyers and sellers (Loft et al. 2014). Upstream downstream conflicts due to lack of proper conditionality, institutional, and legislation framework for negotiation and inadequacy in explicit policy provisions for revenues and resource use were seen as major problems in Nepal (Bhatta et al. 2015). Mediation role of government and subsidiary organizations for biodiversity conservation, systematically addressing values of ecosystem services, priorities on the investment, and more participatory approach is required in the PES type schemes followed in Nepal so far (Bhatta et al. 2014; Rai et al. 2016).

\section{Materials and methods}

\section{Study Area}

Major domain of this research is the geographically heterogeneous stakeholders involved in drinking water supply scheme at buffer zone of Sundarijal watershed of Shivapuri Nagarjun National Park (SNNP) $\left(27^{\circ} 45^{\prime}\right.$ and $27^{\circ} 52^{\prime}$ North to $85^{\circ} 15^{\prime}$ and $85^{\circ} 30^{\prime}$ East) (Figure 1). It lies at an altitude of 1320-2732 masl. Purposeful selection of largest watershed of Nepal was done because Sundarijal watershed has immense potential for a PES. Sundarijal has water provision for coverage in 4000 ha land and fulfills $60 \%$ of water demand of Kathmandu valley, among which $40 \%$ of supply is covered by the surface drinking water (Kunwar 2008; Pandey 2016). This area is rich in biodiversity and has a high potential of PES in terms of drinking water and eco-tourism through fresh air, recreation, aesthetic beauty, religious importance, and research (Kunwar 2008; Pandey 2016). 


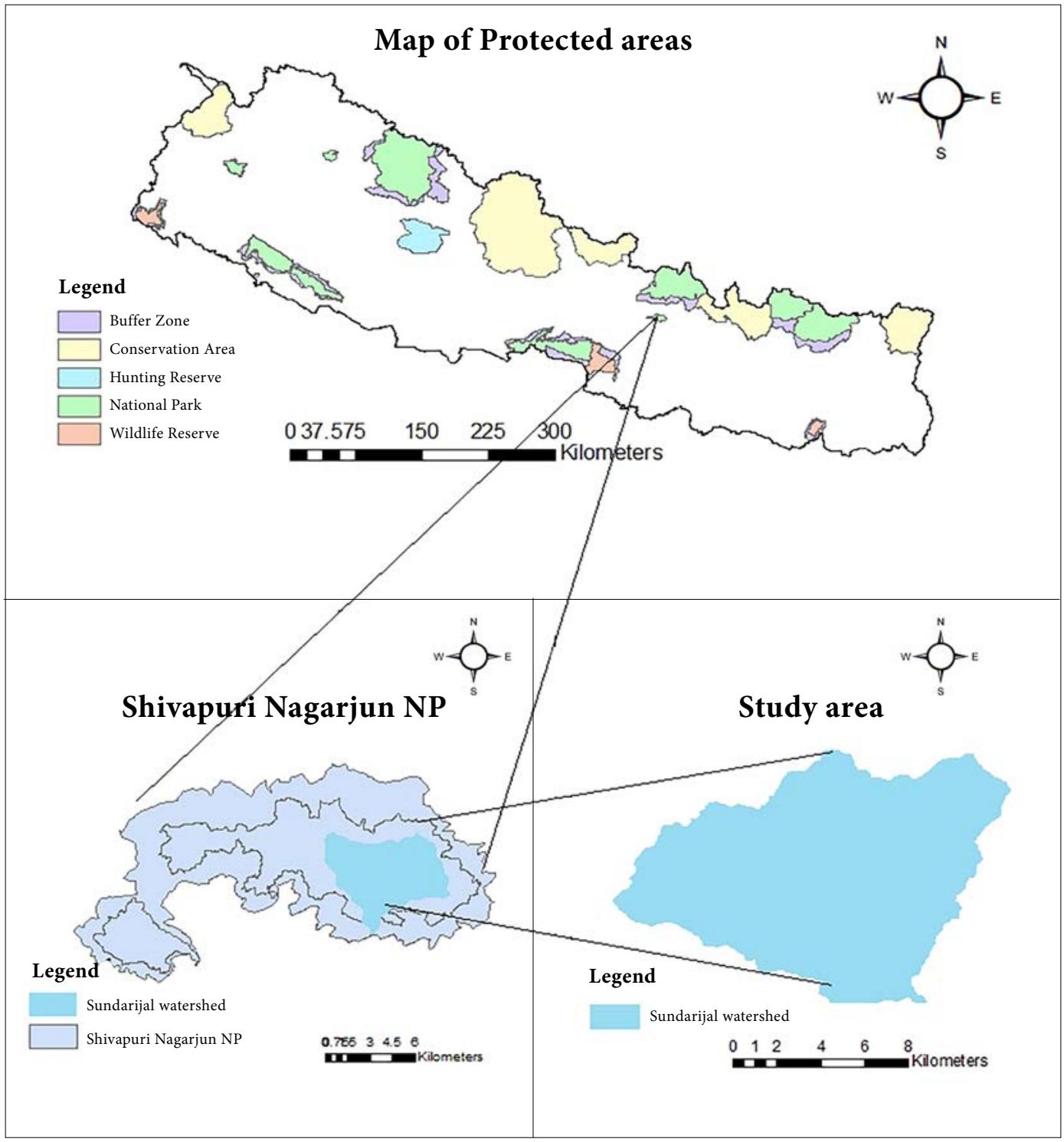

Figure 1: Map of the study site

\section{Conceptual Framework}

Different relevant factors have an impact on execution of a PES mechanism. The study examined the existing drinking water supply scheme and assessed whether it can be referred to as PES. The study identified the problems as a formal PES mechanism is not followed (Figure 2). If existing payment mechanism followed the criteria defined by Wunder (2005), challenges and opportunities for meeting such criteria were investigated. By diagnosing the problems and challenges and opportunities, we can draw the changes required to make a formal PES. The study of the prevalent payment mechanisms of drinking water supply scheme allows an understanding of gap between present practice and formal PES scheme and thus provides prioritized list of changes required to improve present scenario in order to develop a formal PES scheme in the study site. 


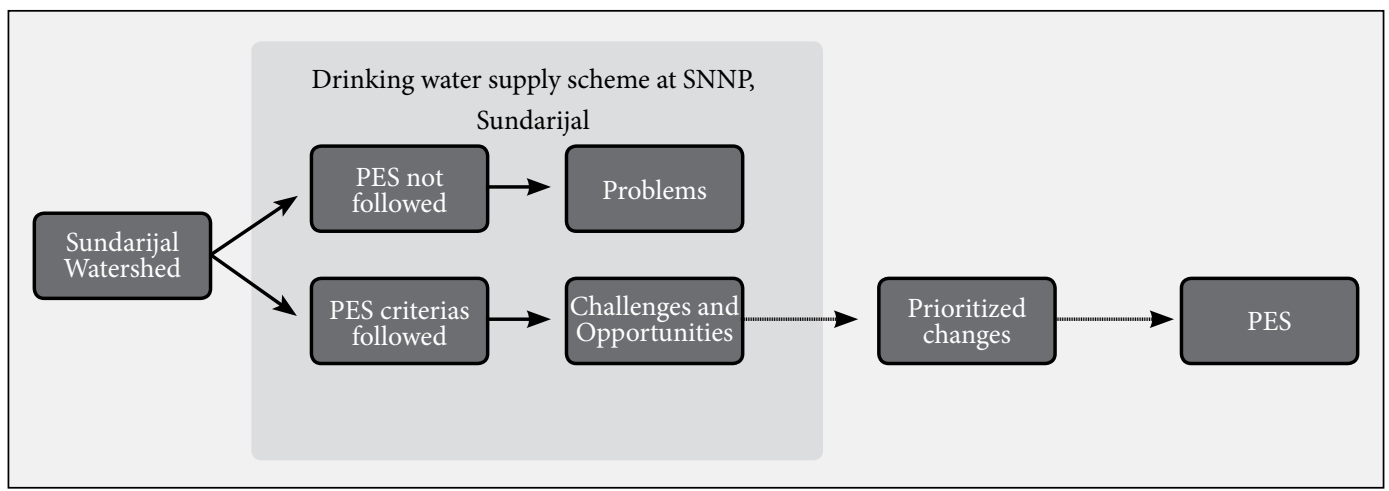

Figure 2: Conceptual framework of the study. Regular arrow presents already prevalent scenario and dotted arrows present the gap which requires filling to establish a formal PES based system in the study area.

\section{Data collection}

Phenomenological cross-sectional research approach (Belotto 2018), Chilisa and Kawulich 2012) was designed for this qualitative study. The philosophical assumption here is the participatory knowledge claim. The strategy of inquiry followed is a case study using the open-ended questionnaire, and Key Informant Interview (KII) (Kabir 2016) as practice of research. Validation of findings was done by triangulation using transcription of interviews as explained by Creswell (2009).

Primary data was collected from telephone survey amongst key informants while the secondary information was obtained from in-depth document review through different journal articles, publications of organizations like Kathmandu Upatyaka Khanepani Limited (KUKL), and annual reports of buffer zone of Shivapuri Nagarjun National Park.

Thirty key informants were selected as explained by Stearns (2012) based on their current involvement in the drinking water supply scheme, representing the geographical heterogeneity, using purposive network sampling in drinking water supply scheme of SNNP buffer zone, each representing local government officials of Shivapuri and Panimuhan Office, both upstream and downstream user group management committee members, and user group members and officials from implementing partners like KUKL. Details of the respondents is as shown in Table 1. The recorded telephone interviews were transcribed and analyzed to identify challenges associated with trade of ecosystem services. The time duration of the study was eight months, starting from February 2020 and ending in September 2020.

\section{Data analysis}

The recordings of interview were subjected to manual transcription and three-part coding was

Table 1: Details of the KII respondents

\begin{tabular}{clc}
\hline S. No. & Participant details & Number \\
\hline 1 & $\begin{array}{l}\text { Number of informants } \\
2\end{array}$ & $\begin{array}{l}\text { Total no. of male } \\
\text { informants }\end{array}$ \\
3 & $\begin{array}{l}\text { Total no. of female } \\
\text { informants }\end{array}$ \\
4 & $\begin{array}{l}\text { User's group committee } \\
\text { members }\end{array}$ \\
& $\begin{array}{l}\text { Buffer zone management } \\
\text { committee (BZMC) }\end{array}$ \\
& $\begin{array}{l}\text { SNNP, } \\
\text { Panimuhan Office } \\
\text { respondent, BZMC. } \\
7\end{array}$ & 3 \\
Officers from SNNP and & KUKL & 3 \\
\hline
\end{tabular}

Source: Telephone interview, SNNP study site, 2020. 
done following Stearns (2012). First part was line to line coding, whose report was subjected to axial coding to enlist the problems which were further grouped under wider themes. The themes were counted for their frequency of appearance in case of each participant's response and average value of frequency was calculated for each theme. The themes with maximum frequency were ranked as a top priority, plotted and presented with the help of radar diagram. AtlasTi version7 and MS-Excel was used for the quantitative data analysis and frequency calculations. For factual questions, responses were directly compiled into the result section.

\section{Results and Discussion}

\section{Prevalent drinking water supply scheme}

Drinking water supply scheme in the study area is 50 years old. Panchayat government under Jog Meher Shrestha had allocated budgets for building the tank, work was done by voluntary labor of local residents and pipes that extended up to $1 \mathrm{~km}$ from source were bought by collective fund. One tap for the whole village was run on queue-based system by 1981 . There was a collection system by 1988 when tank of ward no. 3 was made and distribution pipe line was extended to nearby wards. The national park which accommodates study site is SNNP. This Park has prioritized construction of a basic design of a PES mechanism as a management strategy in its present management plan (SNNP 2017).

\section{Existing payment mechanism in drinking water supply scheme SNNP}

There is a drinking water users' committee that pays for the use of water to the local government body for the service provided, thus, the payment scheme being followed is a public-private type. Payment is in cash in the scheme as paid by the users and on a periodic basis. The payment system is shown in Figure 3.

Water using beneficiaries' household formed a group - water users' group, which collect money on a monthly basis from the households for consuming drinking water. The collected

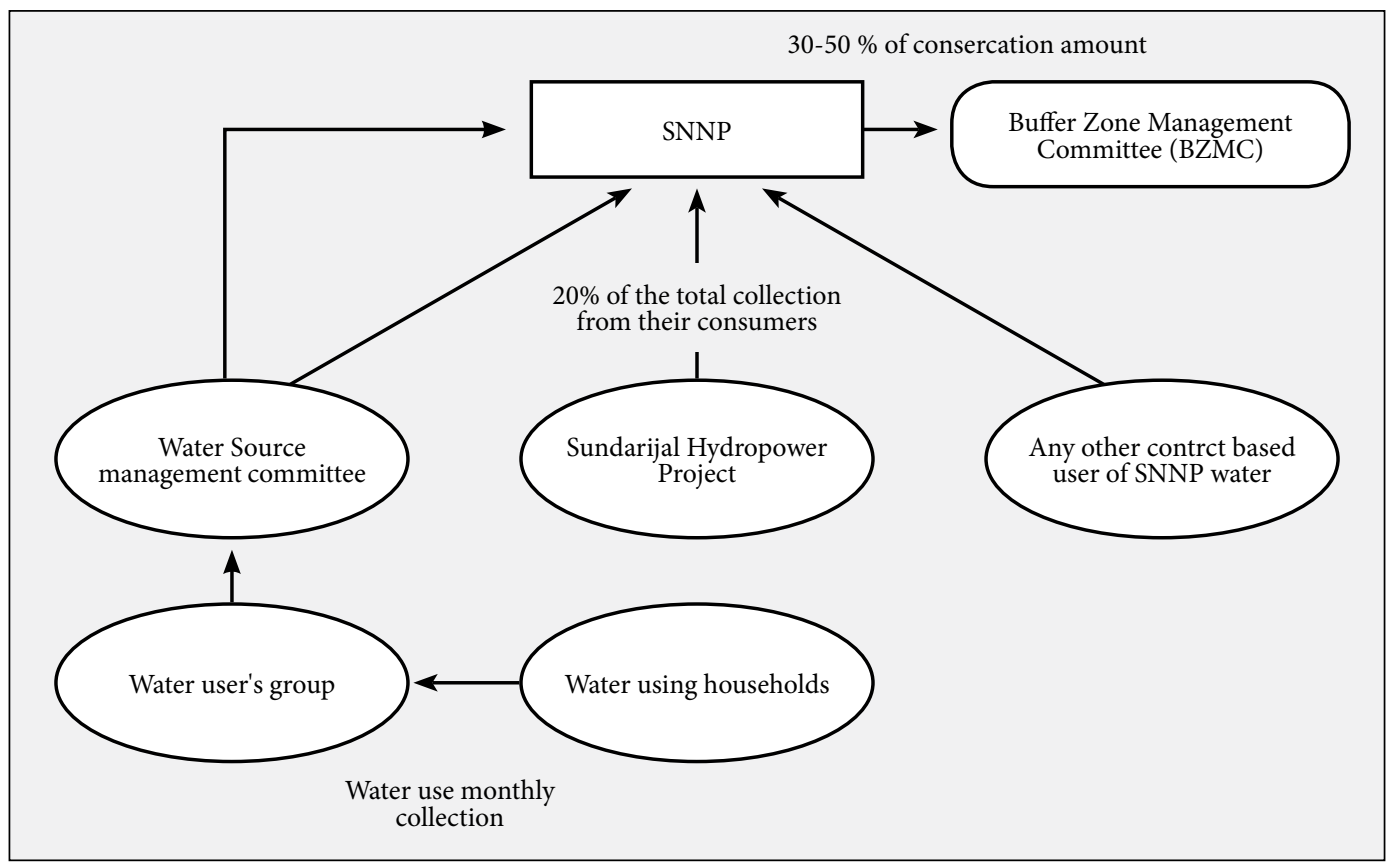

Figure 3: Fund flow of the prevalent drinking water supply scheme 
money is paid to Water Source Management Committee (WSMC). SNNP collects the money for water use from WSMC and other users. Twenty percent of such collected money is re-distributed to Buffer Zone Management Committee (GON 2019). The money thus collected is spent on maintenance and staff remuneration and does not flow to further productive use.

\section{Components of formal PES and their existing status in the study site}

1. Rules and enforcement: In Sundarijal, formal rules of PES mechanism have not been established till now. By far, the formation of authorized stakeholders in the form of Users'Committee and Buffer Zone Management Committee have been set. Jaladhar Samrakshyan Ain (Water Conservation Act) 1960, amended National Park and Wildlife Conservation Act, 1973 and recent SNNP BZMC guidelines of 2019 are government issued rules (GON 2019). The local people and user committee members are not aware of all these laws. However, they are well aware about the latest BZMC guidelines only which enforces a payment system among water users. However, there is a clear violation of the rules regarding pipeline size and entry inside the park, as stated by multiple stakeholders. Stakeholders also claimed that major user of water, Kathmandu Upatyaka Khanepani Limited (KUKL) has refused to pay for the water it has consumed. The refusal of KUKL to pay for water use has not only caused an uproar among the communities upstream, but also made it difficult to persuade them to pay.

2. Buyers, sellers and configuration: There are no practical buyers and sellers in Sundarijal at present. Water source management committee is responsible for receiving the money from multiple users (members of water users group that reside around five kilometers from water collection tank of their source), the configuration of payment can be considered many to one. Though demands for water from adjacent municipalities is a scope of PES establishment, no formal structure for sales of water is prevalent.

3. Mode of payment: The mode of payment in the existing water supply scheme transaction is close to many to one output based, because the members of water users group, who form a committee to register their source, pay a fixed amount of money on monthly basis (which varies among the committees but the range starts from NRs. 50 to 250 per month) for the use of water to a water source management committee. The supply schemes are temporary ones and incorporates only short-term costs.

\section{Framework for study of monitoring of} PES and its management: The monitoring of activities and any problems within buffer zone is dealt by making drinking water committee. One of the key stakeholders reported: "The conflict among upstream users is prevalent these days. Whoever registers competes to collect the water from upstream of a source above the collection chambers of other users prevailing. To resolve these problems, there have been coordination meetings with these groups by the $\mathrm{BZ}$ management committee. Water is limited, and people intend to compete. So, in order to control this, they are holding meetings."

\section{Steering group/scientific advisory panel}

Monitoring and stakeholder's consultation about payment scheme has not been possible in Sundarijal, the only consultation they had was for the two formal recommendations (One, from the local government officials and the other, from SNNP) to construct water collection chamber that are required as per rules of SNNP. Thus, the only scientific panel they get support 
from is through local government office and SNNP monitoring officer who approve the plan.

Scheme: The "scheme of payment" being used by the locals in BZ area in the study site is "use restricting" type because there are rules governing the size of collection pipeline and location of construction of collection chamber, use of paid hand written entry passes that restrict the individual's use of water from SNNP, and only use of water can be made through a registered water user's committee.

\section{Spatial boundaries of drinking water supply} scheme: The boundaries are set in terms of household numbers that fall under a single user's group and a Users' group committee who wish to manage and use the drinking water from a source. The scheme type present at the site does not resemble to any popular scheme type of PES.

\section{Benefit sharing mechanism in drinking water} supply scheme: The benefit sharing mechanism exists in between SNNP and the locals through different committees in a compensatory manner from the BZMC.

This study found payment for ecosystem service has not been formally established in the study site, however, it has immense potential to establish a formal PES mechanism. Fulfilling all the criteria for PES is not common in the world, however there have been cases where a scheme follows multiple criteria of PES (Wunder 2005). The prevalent payment scheme in the study site is payment in cash on a periodic basis, and public-private type as explained by Smith et al. (2013) which can be sustainable.

\section{Institutions engaged in the water supply scheme}

The major stakeholders of Drinking Water Supply Scheme in Sundarijal were Water Users (WUs), Water Users Committees (WUCs), Buffer Zone Management Committee (BZMC),
Sundarijal Hydropower project office and SNNP. Water users, Water Users Committees, BZMC are connected with SNNP (Figure 4).

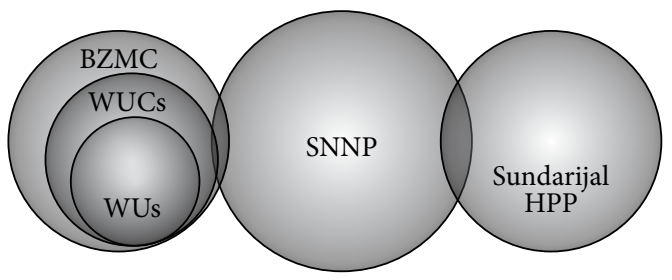

Figure 4: Major stakeholders involved in drinking water schemes prevalent in SNNP buffer zone Sundarijal in $\mathbf{2 0 2 0}$

But KUKL is neither connected with water users' committee nor with SNNP directly.

The upstream users are collecting water from rivers, streams, and small drainage streams for their drinking water purpose, household consumption and agricultural purposes. KUKL is independently collecting water and supplying without an appropriate collaboration with locals. The drinking water distribution is mainly led by the hydropower and is seen as a liability of Sundarijal hydropower.

This study pointed out inadequate involvement of associated institutions in terms of arranging fund and benefit sharing. Fauzi and Anna (2013) recommend checking yearly budget arrangements and involvement of multiple local partners through the merge of the financial aspect of the institutions. Preparation of good plan and searching financial and technical assistance for raising adequate fund was successful in establishing PES mechanism in Latin America (Stearns 2012).

\section{Problems prevalent in drinking water supply scheme}

The prevalent problems were identified and prioritized on the basis of frequency of problem stated by each respondent during KII (Figure 5). Majority of the informants prioritized poor condition of the users, disagreement to sell water, inadequate water for source users, 
Prioritized prevalent problems in Drinking water in Sundarijal watershed

Poor condition of users; difficulty to pay for water

Improper regulation of rules and policies Disagree to sale water

Difficulty in maintenance of water source

Laggard problems

Inadequate baseline information on water sources

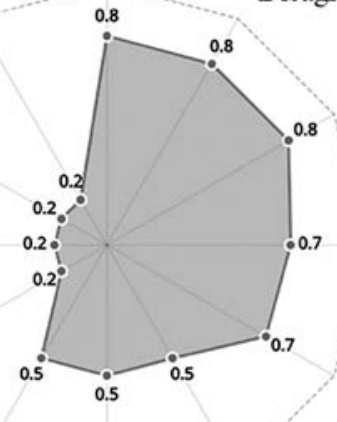
Inadequate water for source users

Inadequate Fund

Technical issues in water collection chambers

Quality of drinking water

SNNP rules conflict with interest of users downstream

Figure 5: Prioritization of prevalent problems in drinking water scheme of Sundarijal watershed (Scale: The range of values each problem line symbolizes in the diagram is 0 to 1 )

inadequate fund, and conflict with KUKL as important problems. Major prioritized problems are explained below.

\section{The condition of poor users}

About 10 percent of households in every group are below poverty those who cannot afford a metered connection for water supply. In such a scenario, lack of any external funding and inadequate collected funds causes problems in arranging appropriate distribution, maintaining staff salaries, and payment system.

This study found poor income state of the watershed users was primary problem in the study area. Prajapati (2012) reported that watersheds can be basis of income for the people, and if the income is directed towards pro-poor, it can be a measure of economic relief for the pro-poor.

Another problem reported in this study was due to re-structuring of the state and difficulty to convince the laggard population. Formation of good network by involving multiple organizations as intermediaries (Stearns
2012) and setting an example by establishing a formal PES mechanism to influence laggards (Dongol 2004) to follow a good trend are some possible. Since PES measure aims for the cost reduction using best approach, its scope is immense in case of a watershed like Sundarijal.

\section{Reluctance to sell water}

The present water supply is one door, one tap system. This is under the pressure of laws enforced by SNNP, which restricts the use of pipes more than one inch for collection chamber. It does not allow the collection of enough water in the tank. The water is, therefore, being supplied twice a day, and in dry times, once a day: either in the morning or the evening. In this kind of scenario, it is difficult to make everyone in the committee agree to sell water to a third party. Thus, the creation of appropriate "seller" for PES has been difficult.

\section{Inadequate water for source users}

The water distribution is done among the user's committee member households. It is 
inclusive of far-residing people, female and minorities. The water distribution is done up to households starting 2.5 kilometers to 5 kilometers of distance from the tank in pipeline distribution. The number of sources and system of distribution is inadequate for users upstream and often causes conflict and competition among the locals making it challenging to bring people in common understanding. The locals blame earthquake, as well as deforestation to aid the drying of previously prevailing springs. Earthquake has also damaged the water tanks which are being used by repairing. Thus, there is lack of water for selling in upstream which does not allow PES transaction to start with. There exists turbidity problem and repeated need of repair due to the sediments. Higher household income and better maintenance of catchment area was ensured after PES was followed in similar case in Indonesia (Budhi et al. 2008). For the sake of improved quality of tap water, people get ready to pay up to double the original price around Kathmandu valley (Prajapati 2012). The case was upto $13 \%$ higher in Kulekani (Khatri 2010).

This study highlighted the lack of established relations between PES actors, incapability of paying for water among the water users, lack of quantified number of buyers as a major problem for the establishment of a PES mechanism. The proposed solution to cope with these problems was sufficient awareness raising among the stakeholders involved in the drinking water supply scheme network in similar case in Laos (Mousques et al. 2007).

\section{Inadequate funds}

Poor economic condition, inadequate external funding and little government support constrain the establishment of a well-managed delivery system for water sales as per PES scheme.. According to the Buffer Zone Management Plan budget mentioned in the annual report of SNNP (2017), the fund of SNNP has no heading specifying PES in SNNP. Watershed and Wetland Management encompasses NRs. 30,00,000 for 5 years. Under present conditions, each user's committee receives an amount of NRs. $2,50,00,000$ in all headings, the distribution is shown in Figure 6.

The amount of money allocated to spend on

Figure 6: Five-year (2017-22) budget allocation of WUCs (SNNP 2017)

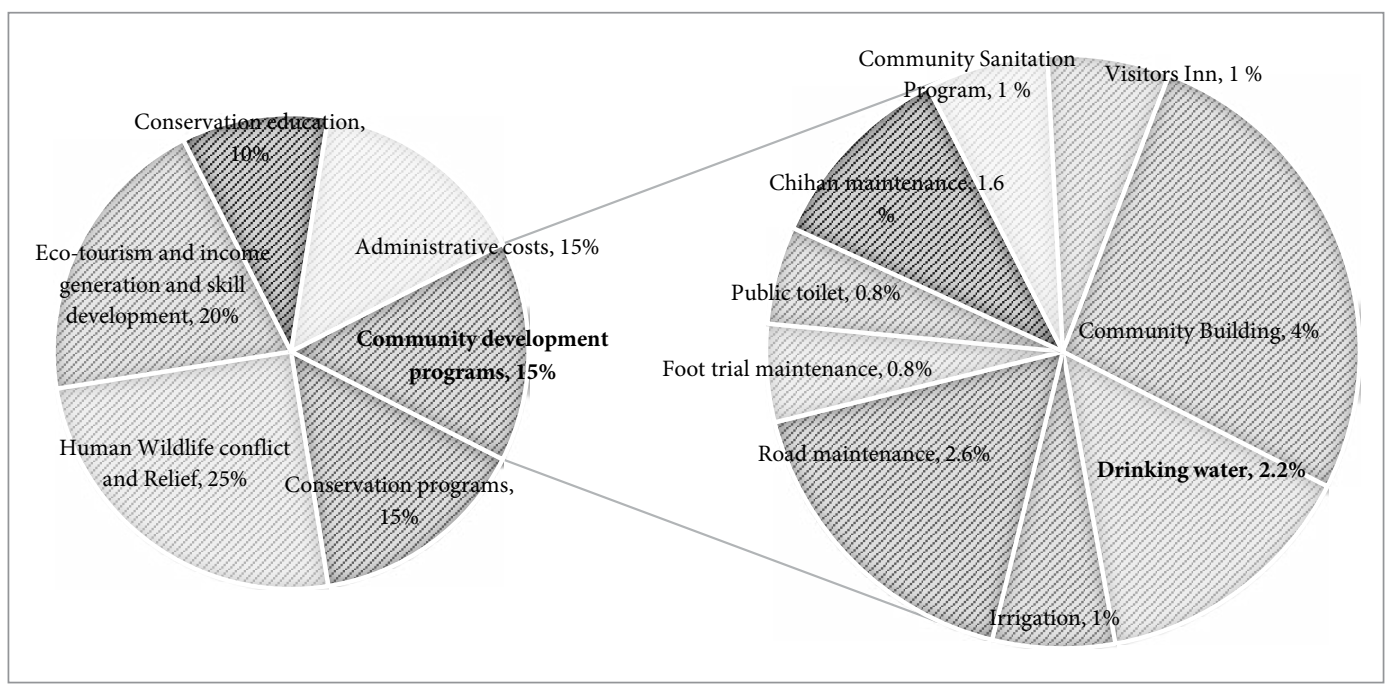


drinking water scheme (allocated only by three WUCs) as per the regulated plan was about NRs. per 400000 for 5 years. This amount is negligible considering the present need of the WUCs. As clarified by Fig. 6, though it has been prioritized in the annual report, no actual budget allocation has been done for PES, and drinking water supply by SNNP and this has to be prioritized under various conservation programs heading, which is not very assuring towards achievement of a long lasting PES mechanism.

People are using electricity from the watershed and paying bills to the authorized committee. The local people are not getting any payment in the region. In such situations, they need help of multiple organizations to run any other mechanism such as PES.

\section{Conflict with KUKL for fund}

Residents of Sundarijal have a history of distrust of KUKL as it has been exclusive commitment towards its customers and non-compliant to the rule of payment or any cash or kind support to the locals. Thus, people think that KUKL only intends for its profit, and does not want to prioritize their concerns and issues.

Following is the part of the statement from respondent, $60 \%$ of the water of KUKL is from Sundarijal. In 2076 Jestha 6, the Cabinet has decided that ed SNNP has to be paid 20\% money by KUKL for using water. KUKL refuses to pay. KUKL sells water and swallows all the money.

Gokarneshwar site is the major hub of water collection for KUKL. However, the cash and kind services have not been satisfactorily paid back to the locals which is why locals are not happy with KUKL in this region.

Apart from these major problems, not having proper quality drinking water supply due to lack of water filter system at collection tanks, procedural delay during registration,
EIA and IEE on establishment of new tanks, higher demand of water from downstream but restrictions on amount of water harvest by SNNP and others as shown in Fig 5, are some of the problems highlighted from the KII.

Despite larger demand of water, the upstream population do not seem to be interested in selling water because of the prevailing situation of freeloading on the water resources by private institutions and KUKL. Establishment of proper PES mechanism can be supportive in increasing the availability of resources in a conditional manner for their own use, and also to provide economic incentives that will ease the fund problems as shown by multiple examples (Aryal et al. 2021; Poudyal et al. 2021).

\section{Opportunities for the development of PES scheme}

Decreased population on some areas due to earthquake resettlement has reduced the pressure on distribution so collection chambers have more water reserved. It can be a good opportunity to initiate a PES scheme by formal sales of such water. As per the rule of "one source one, user committee" by SNNP, sources of water like small rivers and streams can be utilized for additional water collection and finally start formal sales of water. The need for filter plant in most of drinking water plants can be used as a good "kind" payment scheme. This will help increase in the amount of water saving in the tank during monsoon, due to filtering of dirty water, which will aid in selling water throughout the year consistently. From history, the water management in this area is being done by the committees, without any external help. ES users are capable of internally organizing payments. They have good knowledge about water sources, and their skill upgrading along with use of this traditional knowledge can be an opportunity to start PES and govern it locally. Working on forming a baseline document for PES is still an opportunity in the study site. 


\section{Expectations of stakeholders to improve (drinking water supply of Sundarijal watershed)}

Majority of the stakeholders agreed on the need for improving the existing drinking water supply scheme to formal PES. They suggested changes in developing a PES scheme in SNNP. First of all, payment from KUKL should be ensured as per rules. Clean drinking water should be prioritized and filter plants need to be established in all collection chambers. Furthermore, fund should be secured and mobilized to construct tanks to collect water in the dry season as well as add filters on the existing chambers. Increasing number of visitors had negative impacts on the environment, for example: water resources are polluted. Therefore, the number visitors and precautions to conserve the environment should be carefully assessed. Opportunity to sell water needs to be increased by building additional ponds for monsoon water collection and solve the water availability problem. Separate SNNP regulation emphasizing PES is required for the study site as at present, PES is only a strategic idea of SNNP. SNNP must be more concerned and allocate more budget for watershed resource conservation and utilization. Collaboration with stakeholders and involvement of multiple stakeholders in conflict resolution, fund collection and local problem solving. Thus, to create a situation of PES, the stakeholders wish to increase the amount of water storage, decrease the conflict of entering with a pass, and serve to decrease human-wildlife conflict.
Expectations and priorities of the water users and people residing in study site are more towards providing cleaner drinking water, and if possible, in greater amounts. The prioritized activities in the region are the construction of additional water tanks with filter plants so that amount of water collected can be more, and consistent throughout the year. If succeeded in their present endeavors, the present drinking water supply schemes of SNNP, Sundarijal, which are in temporary condition, will soon be able to save water for sale. PES mechanism is highly recommended to create win-win situation to deal with upstream-downstream conflict on the use of watershed resources.

\section{Conclusion}

The prevalent payment scheme in the study site was found to be payment in cash on a periodic basis, and public-private type, which does not accord to the formal PES mechanism. Poor condition of the users, disagreement to sell water, inadequate water for source users, inadequate fund and conflict with KUKL are primary challenges that constrain a formal PES scheme establishment at the study site. There are multiple water resources inside SNNP, which require identification and thus the potential for PES establishment is high in the region. Through adequate fund allocation for construction of infrastructures, building up of institutional collaboration and baseline document preparations, accelerated development of PES can be obtained in the study area. 


\section{References}

Aryal, K., Ojha, B. R., \& Maraseni, T. (2021). Perceived importance and economic valuation of ecosystem services in Ghodaghodi wetland of Nepal. Land Use Policy, 106, 105450.

Belotto, M. J. (2018). Data analysis methods for qualitative research: Managing the challenges of coding, interrater reliability, and thematic analysis. The Qualitative Report, 23(11), 2622-2633.

Bhatta, L. D., Pandit, A. \& Manandhar, U. (2015). Internal report. In A. Sellmyer (Ed.) Proceedings of the National Workshop on Payment for Ecosystem Services: Opportunities and Challenges in Nepal. International Centre for Integrated Mountain Development (pp. 1-43). Kathmandu, Nepal.

Bhatta, L. D., Van Oort, B. E. H., Rucevska, I. \& Baral, H. (2014). Payment for ecosystem services: Possible instrument for managing ecosystem services in Nepal. International Journal of Biodiversity Sciences, Ecological Services and Man, 10(4), 289-299. Retrieved from https:// doi.org/10.1080/21513732.2014.973908

Budhi, G.S., Kuswanto, S.A., \& Iqbal, M. (2008). Concept and implementation of PES program in the Cidanau Watershed: A lesson learned for future environmental policy. Analisis Kebijakan Pertanian, 6(1), 37-55.

Chilisa, B. \& Kawulich, B. (2012). Selecting a research approach: Paradigm, methodology and methods. In, C. Wagner, B. Kawulich, \& M. Garner (Eds.), Doing Social Research: A global context (pp. 51-61). McGraw Hill Higher Education, Maidenhead, Berkshire.

Creswell, J.W. (2009). Research Design. Qualitative, Quantitative and Mixed Methods Approaches (3rd ed., pp. 270). USA. Sage Publications. Inc. Thousand Oaks, California.

Dhakal, B., Khadka, M. \& Gautam, M. (2020). Impacts of payment for ecosystem services of mountain agricultural landscapes on farming women in Nepal. GeoJournal, 86(3), 1389-1423.

Dongol, B. B. S. (2004). Extension Education. Dongol printers, Gophal Tole, Kathmandu.

Engel, S., Pagiola, S. \& Wunder, S. (2008). Designing payments for environmental services in theory and practice: An overview of the issues. Ecological Economics, 65(4), 663-674.
Fauzi, A. \& Anna, Z. (2013). The complexity of the institution of payment for environmental services: A case study of two Indonesian PES schemes. Ecosystem Services, 6, 54-63.

GC, D.B., Bhandari, J., Shengkui, C., Shaofeng, J., Can, L. \& G.C. Ramu. (2018). Payment for Ecosystem Services in Nepal: A Literature Review on Overview and Recommendations for Further Research. Acta Scientific Agriculture, 2(11), 37-42.

Government of Nepal. (2019). Shivapuri Nagarjun Rastriya Nikunja Niyamawali, 2019. Retrieved from http://rajpatra.dop.gov.np/ welcome/book/?ref=23687

Greiber, T. (Ed.) (2009). Payments for Ecosystem Services. Legal and Institutional Frameworks. IUCN, Gland, Switzerland. 78, 296. Retrieved from https://www.iucn.org/downloads/ eplp_78_1.pdf

Huang, H. \& Poudyal, A. (Eds.). (2013). Payment for Ecosystem Services in Nepal Prospect, practice and process. IUCN Nepal report, Kupondole, Lalitpur, Nepal. Retrieved from https://www. iucn.org/sites/dev/files/import/downloads/ payment_for_ecosystem_services_in nepal_prospect_practice_and_process.pdf

Kabir, S.M.S. (2016). Basic Guidelines for Research. Book Zone Publication, Chittagong- 4203, Bangladesh.

Khatri, D. B. (2010). Payments for ecosystem services in Kulekhani Watershed of Nepal: An institutional analysis of mechanisms for sharing hydroelectricity revenue. 13th International Association of Study of Commons Conference at Hyderabad, Hyderabad, 10-14 January 2011, 1-60. Retrieved from: https://www. semanticscholar.org/paper/Payments-forEcosystem-services-inKulekhani-of-\%3AKhatri/393d5354bd775c4b683a03bc973dfd7 69fddafca

Kathmandu Upatyaka Khanepani Limited (2019). Kathmandu Upatyaka Khanepani Limited. Annual Report. Twelfth Anniversary. Retrieved from http://kathmanduwater.org/ wp-content/uploads/2021/03/Annual\%20 Report\%202077.pdf

Kunwar, K. J. (2008). Payment for Environmental Services in Nepal (A Case Study of Shivapuri National Park, Kathmandu, Nepal). The Initiation, 2(1), 63-72. 
Loft, L., Thuy, P. T. \& Luttrell, C. (2014). Lessons from Payments for Ecosystem Services for REDD+ Benefit-Sharing Mechanisms. CIFOR info brief, 68. Retrieved from https://www.cifor. org/publications/pdf_files/infobrief/4488infobrief.pdf

Malavasi, O. E. \& Kellenberg, J. (2002). Program of Payments for Ecological Services in Costa Rica. Retrieved from https://vtechworks.lib.vt.edu/ bitstream/handle/10919/66992/2491_ Ortiz2002_Program_PES_Costa_Rica. doc? sequence $=1$ \&isAllowed $=y$

Montoya, J. M., \& Raffaelli, D. (2010). Climate change, biotic interactions and ecosystem services. Philosophical. Transactions of the Royal Society B., 365(1549), 2013-2018.

Mousquès, C., Sengsoulychanh, P., Sengtaheuanghoung, O., Latchackack, K., Ribolzi, O. \& Pierret, A. (2007). Relevance of

Payments for Environmental Services (PES) for Watershed Management in Northern Laos. Retrieved from https://www.researchgate. net/publication/254757885_Relevance_of_ Payments_for_Environmental_Services_ PES_for_Watershed_Management_in_ Northern_Laos

Pandey, J. (2016). Payment for Ecosystem Services (PES) Schemes in Shivapuri Nagarjun National Park. International Journal of Scientific and Engineering Research, 7(11), 1682-1758.

Pedersen Zari, M. (2015). Ecosystem services analysis: Mimicking ecosystem services for regenerative urban design. International Journal of Sustainable Built Environment, 4(1), 145-157.

Pereira, H. M., Navarro, L. M., \& Martins, I. S. (2012).Global biodiversity change: The Bad, the good, and the unknown. Annual Review of Environment and Resources, 37, 25-50.

Poudyal, B., Upadhaya, S., Acharya, S. \& Khanal Chhetri, B.B. (2021). Assessing SocioEconomic Factors Affecting the

Implementation of Payment for Ecosystem Services (PES) Mechanism. World, 2(1), 81-91.

Prajapati, M. (2012). Scope of Payment for Ecosystem Services Mechanism for better water and watershed management in Bhaktapur (Masters' thesis). Khwopa College, Tribhuvan Univertsity, Nepal.
Rai, R., P. Shyamsundar, L. Bhatta, and M. Nepal (2016). Designing a Payment for Ecosystem Services Scheme for the Sardukhola Watershed in Nepal. SANDEE Working Paper, 108(16),15-17. Retrieved from https:// doi.org/10.13140/RG.2.1.4432.3443

Rosenbach, D. W., Whittemore, J . \& Deboer, J. (2013). Community Forestry and REDD + in Nepal (Masters' thesis). University of Michigan, Michigan, United States.

Samii, C., Lisiecki, M., Kulkarni, P., Paler, L., Chavis, L., Snilstveit, B., Vojtkova, M., and Gallagher, E. (2014). Effects of Payment for Environmental Services (PES) on Deforestation and Poverty in Low and Middle Income Countries: A Systematic Review. Campbell Systematic Review, 10(1), 1-95.

Smith, S., Rowcroft, P., Everard, M., Couldrick, L., Reed, M., Rogers, H., Quick, T., Eves, C. \& White, C. (2013). Payments for Ecosystem Services: A Best Practice Guide. DEFRA, URS 6-8 Greencoat Place London.

Shivapuri Nagarjun National Park. (2017). Shivapuri Nagarjun National Park and Buffer Zone Management Plan. Fiscal Year 074/075-078/079 (2017/018-2021/022).

Retrieved from http://dnpwc.gov.np/media/ publication/Management_Plan_2075_ Shivapuri.pdf

Stearns, H. (2012). Payments for ecosystem services and intermediaries: Investigating potential involvement and programmatic roles in Western Panama (Masters' thesis, Colorado State University Fort Collins, Colorado). Retrieved from https://mountainscholar. org/bitstream/handle/10217/67301/ HuberStearns_colostate_0053N_10911. pdf;sequence $=1$

Sutton, P. C., Anderson, S. J., Costanza, R., \& Kubiszewski, I. (2016). The ecological economics of land degradation: Impacts on ecosystem service values. Ecological Economics, 129, 182-192.

Wunder, S., Brouwer, R., Engel, S. Ezzine-de-Blas, D. Muradian, R. Pascual, U. \& Pinto, R. (2018). From principles to practice in paying for nature's services. Nature Sustainability, Nature, 1(3), 145-150.

Wunder, S. (2005). Payments for environmental services: some nuts and bolts. CIFOR Occasional Paper No.42, 24. 